\title{
Wind energy potential estimation and micrositting on Izmir Institute of Technology Campus, Turkey
}

\author{
B. Ozerdem*, H.M. Turkeli \\ Department of Mechanical Engineering, Izmir Institute of Technology, Urla, 35430 Izmir, Turkey
}

Received 11 June 2003; accepted 16 November 2004

Available online 16 December 2004

\begin{abstract}
The aim of this study was to predict the wind energy content over the campus area of Izmir Institute of Technology. The wind data were collected at 10 and $30 \mathrm{~m}$ mast heights for a period of 16 months. Mean wind speeds were 7.03 and $8.14 \mathrm{~m} / \mathrm{s}$ at 10 and $30 \mathrm{~m}$ mast heights, respectively. The 'WAsP' and 'WindPRO' softwares were used for the wind statistics and energy calculations. Suitable sites were selected according to the created wind power and energy maps. Wind turbines with nominal powers between 600 and $1500 \mathrm{~kW}$ were established for annual energy production calculations and best fitted ones were used for the micrositting.
\end{abstract}

(c) 2004 Elsevier Ltd. All rights reserved.

Keywords: Wind energy; Micrositting; Wind site; Annual energy production; Wind farm

\section{Introduction}

There is a growing awareness for renewable energy resources in Turkey as a result of rapidly increasing population and industrial development. Total electricity installed capacity was 31,846 MW and total electricity production was 129,400 GWh in 2002 . According to the eight Five Year Development Plan prepared by the State Planning Organization, estimated electricity installed capacity and total electricity production are 42,783 MW and 193,900 GWh for 2005, respectively. Since electricity consumption estimation is $195,100 \mathrm{GWh}$, the gap is planned to be imported [1,2].

\footnotetext{
* Corresponding author. Tel.: +90 232498 6519; fax: +90 2324986505 .

E-mail address: barisozerdem@iyte.edu.tr (B. Ozerdem).
} 
Turkey does not possess enough conventional fossil fuel reserves, but possesses rich renewable energy resources such as hydrolic, solar, geothermal and wind. Among all, wind energy seems to be the most suitable renewable energy resource for electricity production. The first and second wind farms in Turkey were installed in Cesme-Izmir in 1998. One with 1.7 MW nominal power capacity, generates 4,500,000 $\mathrm{kWh}$ electricity per year and the other with 7.2 MW nominal power capacity, generates 20,000,000 kWh electricity per year. The last wind farm, so far, with 10.2 MW nominal power capacity was installed in Bozcaada-Canakkale in 2000. It generates 30,000,000 kWh electricity per year. It must be noted that, despite her natural capacity, the usage of wind energy is very limited in Turkey.

In order to provide a broad wind resource assessment over Turkey, the wind characteristics must be studied in detail. Wind resource assessments can be divided into two main areas: regional assessment and micrositting. Regional assessment is overall estimation of the mean energy content of the wind over a large area. Micrositting is to position one or more wind turbines on a land in order to maximize the overall yearly energy output of a wind farm.

During the last decade, advanced computational methods have been developed to gain the data to use in estimation of wind energy potential and micrositting [3-7]. A precise prediction of the wind speed at a given site is essential for the determination of regional wind energy resources. Because of aerodynamic reasons, the power output of a wind turbine is proportional to the third power of the wind speed. It is a fact that, especially in complex terrain, wind energy content may vary significantly from one region to another. Therefore, wind data taken over many years are utilised to calculate wind climatology. European Wind Atlas [8] is a good example of this. Some other wind resource maps such as Wind Atlas of Russia [9] and the Irish Wind Atlas [10] also have been prepared.

According to the European Wind Atlas, the western Anatolia appears to have good wind energy potential. Izmir Institute of Technology campus which occupies 3500 ha area is located on a hilly topography right by the Aegean Sea. Several studies have been done to estimate the potential, especially, in western Anatolia [11-15]. However, further studies are necessary. This article aims to provide a wind energy potential estimation and to perform micrositting study on Izmir Institute of Technology campus in order to bridge this gap.

\section{Material and method}

\subsection{Site selection}

Wind speed and, consequently, wind energy potential are heavily influenced by the surface roughness of the surrounding area of nearby obstacles such as trees or other buildings, and by the contours of the local terrain. Therefore, in most cases, using meteorological data directly will underestimate the true wind energy potential in an area. Mast should be located in the site area where characteristic wind parameters of the location can be measured as a representative of the whole site.

The campus area which is located in Urla, Izmir, occupies 3500 ha area. It includes several hills covered with typically Mediterranean bush. Topography of the region is hilly, 


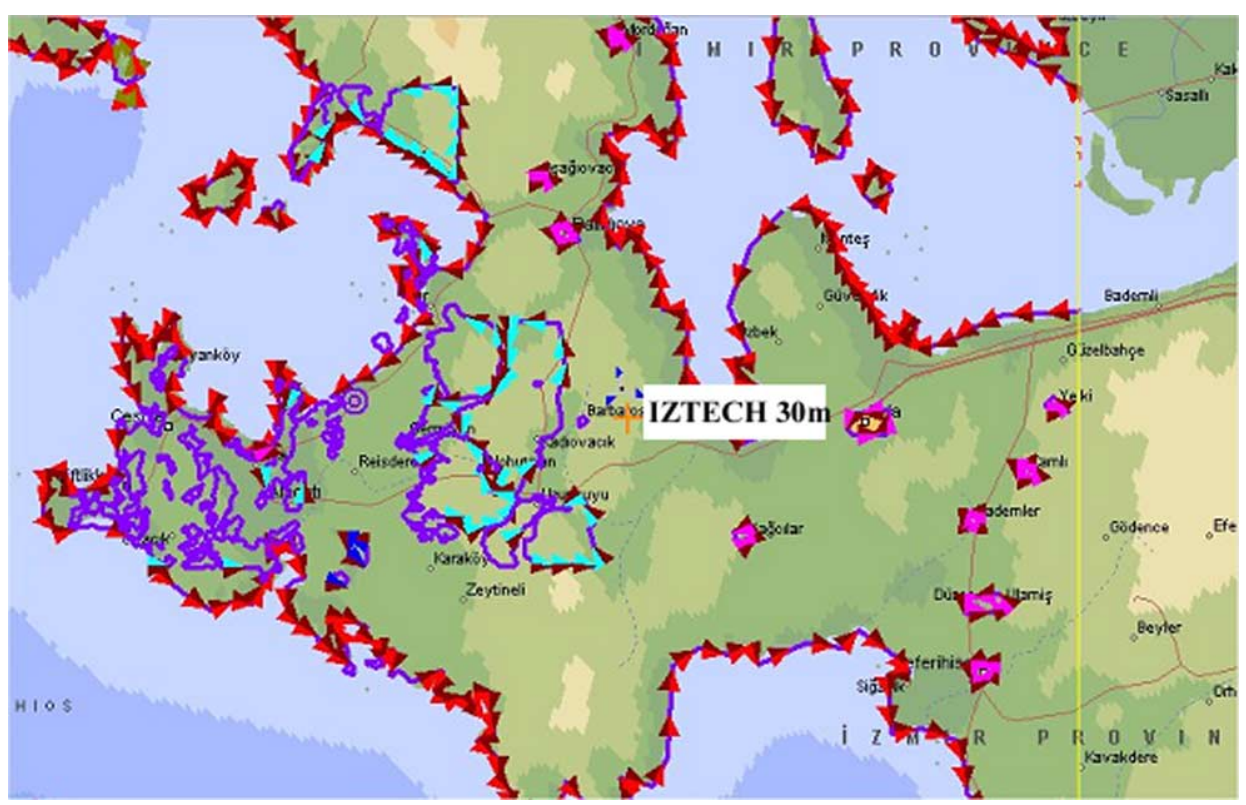

Fig. 1. Location of the mast on Izmir province.

rocky and steep with 15-25\% incline. Soil depth is very low and not suitable for vegetation. No agricultural activity is being practiced in the area.

Site with coordinates 465684 E, 4243843 N (in UTM coordinate system) at $460 \mathrm{~m}$ height was found to be the most suitable location in the area. There were no obstacles detected around the measurement area. Surface roughness was low due to low plant heights, which is important in wind shear. Site was directly open to the sea at north direction. The south and north west directions were covered with higher mountains. Fig. 1 shows the location on Izmir province map.

\subsection{Monitoring station instrumentation}

Measured main parameters were wind speed, wind direction, and air temperature. Table 1 lists the nominal specifications for the sensors used during the measurements. The anemometer consists of a three-cup assembly centrally connected to a vertical shaft for rotation. A wind vane was used to measure wind direction. The temperature measurement was made by a Pt100-resistor composed of three parts: the transducer, an interface device, and a radiation shield.

The data logger mounted on the mast was capable to measure mean, maximum, and minimum wind speeds, prevailing wind direction, and mean temperature. The mast was also equipped with a GSM-system, which makes it possible to make a remote contact with the station by computer or mobile phone. A backup power supply should be included to minimize chances of data loss caused by power failure. This was accomplished by a solar panel and a battery. 
Table 1

Nominal specifications of the monitoring station instrument sensors

\begin{tabular}{llll}
\hline Specification & Anemometer & Wind vane & Thermometer \\
\hline Measurement range & $0-50 \mathrm{~m} / \mathrm{s}$ & $0-360^{\circ}\left(\leq 8^{\circ}\right.$ deadband $)$ & -40 to $60^{\circ} \mathrm{C}$ \\
Starting threshold & $\leq 1.0 \mathrm{~m} / \mathrm{s}$ & $\leq 1.0 \mathrm{~m} / \mathrm{s}$ & N/A \\
Distance constant & $\leq 4.0 \mathrm{~m}$ & N/A & N/A \\
Operating temperature range $\left({ }^{\circ} \mathrm{C}\right)$ & -40 to 60 & -40 to 60 & $40-60$ \\
Operating humidity range $(\%)$ & $0-100$ & $0-100$ & $0-100$ \\
System error & $\leq 3 \%$ & $\leq 5^{\circ}$ & $\leq 1{ }^{\circ} \mathrm{C}$ \\
Recording resolution & $\leq 0.1 \mathrm{~m} / \mathrm{s}$ & $\leq 1^{\circ}$ & $\leq 0.1^{\circ} \mathrm{C}$ \\
\hline
\end{tabular}

Grounding equipment is especially important when using electronic data logger and sensors. Therefore, complete grounding kit provided by the manufacturer was used to protect the system. The tubular type tower, also, was strengthened by guyed wires in order to be kept in vertically aligned position.

\subsection{Methodology}

The data were collected on $1 \mathrm{~h}$ time intervals for first 6 months. Then, time interval rate was changed to 144 data per day by using $10 \mathrm{~min}$ time intervals for the rest of the monitoring period. In this study, the missing data were $3.7 \%$. The 'CALLaLOG' software was used for remote data transferring. The 'WindPRO' and 'WAsP' softwares were played a key role to evaluate all collected data in order to make wind energy analysis and micrositting considering orography and topography at the site.

The expression of kinetic energy of air in wind is

$$
E_{\mathrm{k}}=\frac{1}{2} m V^{2}
$$

where $m$ is total mass of the air, $V$ is wind speed. Since, $m=\rho A V \Delta t$ then,

$$
E_{\mathrm{k}}=\frac{1}{2} \rho A V^{3} \Delta t
$$

where $\rho$ is air density, $A$ is area which air moves, $\Delta t$ is period of time. The power of wind may be expressed as,

$$
P=\frac{1}{2} \rho A V^{3}
$$

and the wind power density may be expressed as,

$$
P_{\mathrm{d}}=\frac{1}{2} \rho V^{3}
$$

The Weibull probability density distribution function used for wind speed is,

$$
p(V)_{\mathrm{w}}=\left(\frac{k}{c}\right)\left(\frac{V}{c}\right)^{k-1} \exp \left[-\left(\frac{V}{c}\right)^{k}\right]
$$


Table 2

Sectoral mean wind speeds and their frequencies at $10 \mathrm{~m}$

\begin{tabular}{llc}
\hline Sector & Mean wind speed $(\mathrm{m} / \mathrm{s})$ & Frequency $(\%)$ \\
\hline North (N) & 7.17 & 78.6 \\
North northeast (NNE) & 7.56 & 4.7 \\
East northeast (ENE) & 3.66 & 0.7 \\
East (E) & 3.88 & 0.7 \\
East southeast (ESE) & 7.71 & 1.5 \\
South southeast (SSE) & 7.21 & 3.2 \\
South (S) & 6.10 & 2.6 \\
South southwest (SSW) & 5.66 & 2.3 \\
West southwest (WSW) & 6.47 & 0.9 \\
West (W) & 5.54 & 0.9 \\
West northwest (WNW) & 5.28 & 1.6 \\
North northwest (NNW) & 6.99 & 2.4 \\
Mean & 7.03 & 100 \\
\hline
\end{tabular}

where $k$ is a dimensionless shape factor and $c$ is the scale factor. The linear approximation of the data is obtained by using the least square method.

Commercially available 'Encarta Digital Atlas' compact disc was used for area map. Digital height counter map which covers area with $5 \mathrm{~km}$ radius and surface roughness map which covers $20 \mathrm{~km}$ radius around measurement point were created and loaded into 'WindPRO' software.

\section{Results}

\subsection{Measurement parameters analysis}

Mean wind speed and Weibull distribution are the most effective parameters in wind energy analysis. Mean speeds were 7.03 and $8.14 \mathrm{~m} / \mathrm{s}$, respectively, at 10 and $30 \mathrm{~m}$ Table 3

Sectoral mean wind speeds and their frequencies at $30 \mathrm{~m}$

\begin{tabular}{llc}
\hline Sector & Mean wind speed $(\mathrm{m} / \mathrm{s})$ & Frequency $(\%)$ \\
\hline North (N) & 8.35 & 74.9 \\
North northeast (NNE) & 8.74 & 5.3 \\
East northeast (ENE) & 3.99 & 0.8 \\
East (E) & 4.20 & 0.8 \\
East southeast (ESE) & 8.94 & 1.7 \\
South southeast (SSE) & 8.31 & 3.9 \\
South (S) & 7.03 & 3.5 \\
South southwest (SSW) & 7.16 & 2.9 \\
West southwest (WSW) & 7.23 & 1.0 \\
West (W) & 5.88 & 0.9 \\
West northwest (WNW) & 5.68 & 1.7 \\
North northwest (NNW) & 8.04 & 2.8 \\
Mean & 8.14 & 100 \\
\hline
\end{tabular}


heights. Calculated mean wind shear values were 0.14 and 0.13 , respectively, at 10 and $30 \mathrm{~m}$ heights.

Prevailing wind direction was north and north northeast on the site. Analysis of Weibull distribution showed that, $78.6 \%$ of the wind at $10 \mathrm{~m}$ and $74.9 \%$ of the wind at $30 \mathrm{~m}$ blew

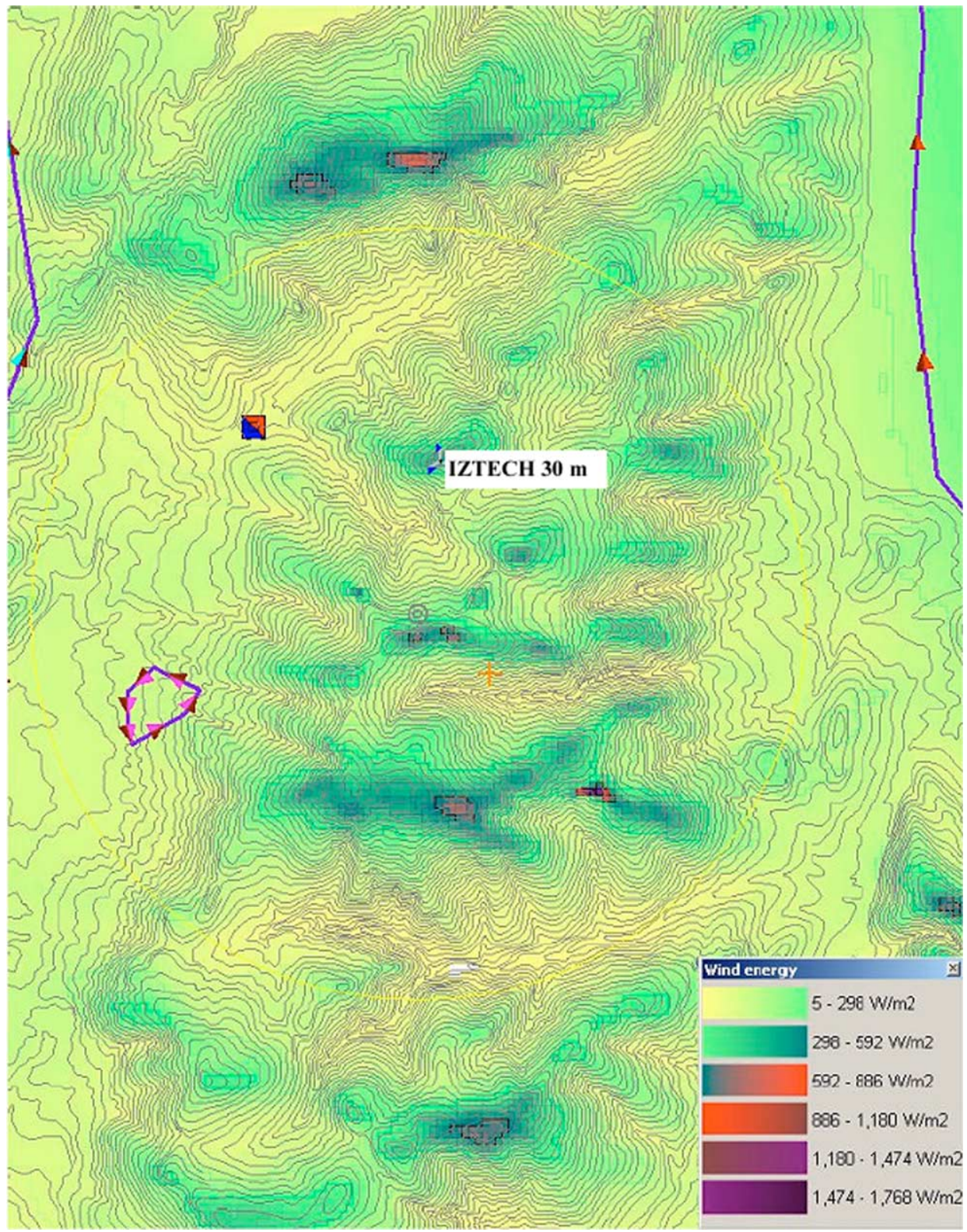

Fig. 2. Wind power map of campus area in $\mathrm{W} / \mathrm{m}^{2}$. 
from north. The frequencies for north northeast sector were $4.7 \%$ at $10 \mathrm{~m}$ and $5.3 \%$ at $30 \mathrm{~m}$. There were strong wind blowing from southern sectors, but their frequencies were quite low. Other sectors' frequencies were not higher than 3.9\%. Therefore, north seems the only wind direction to consider in wind farm project, which will be developed on

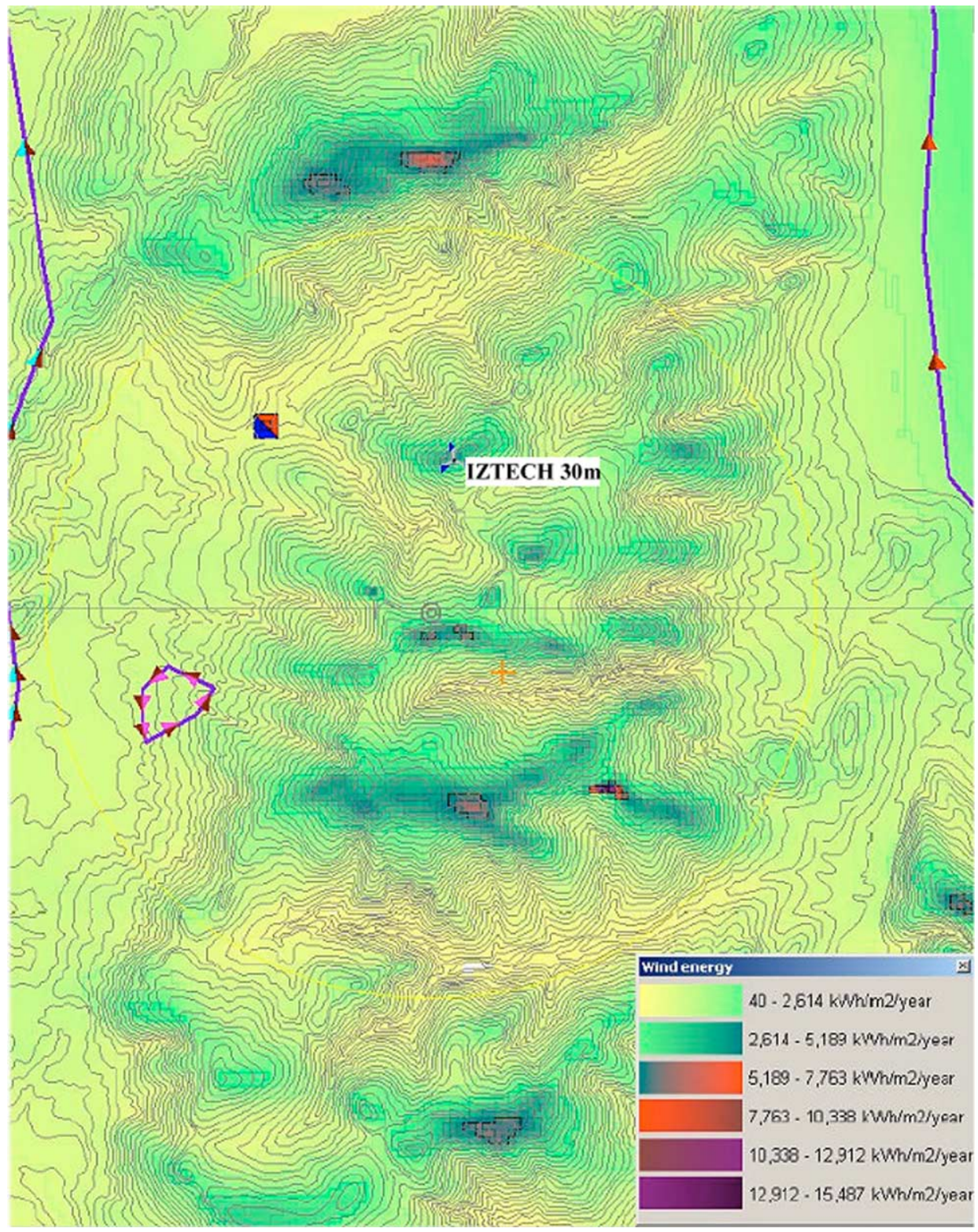

Fig. 3. Wind energy map of campus area in $\mathrm{kWh} / \mathrm{m}^{2} /$ year. 
the campus area. Average temperature was $16.3{ }^{\circ} \mathrm{C}$. The sectoral mean wind speed values along with their frequencies are shown in Tables 2 and 3, respectively, at 10 and $30 \mathrm{~m}$ heights.

\subsection{Wind energy analysis}

Wind energy maps were created by using collected data, orography and roughness maps. Fig. 2 shows the wind power map in $\mathrm{W} / \mathrm{m}^{2}$ by considering only mean wind speed values. The wind energy map, Fig. 3, was determined in $\mathrm{kWh} / \mathrm{m}^{2}$ per year. This map considers whole values of Weibull histogram. Fig. 2 shows eight zones in which wind power value is more than $700 \mathrm{~W} / \mathrm{m}^{2}$. There are also several zones in which annual energy production value is more than $6000 \mathrm{kWh} / \mathrm{m}^{2}$ per year in Fig. 3 .

\subsection{Selecting best fit turbines and micrositting}

Annual energy productions of five turbines with different energy capacities were calculated by 'WindPRO' software using measured data. Nominal powers of these turbines were $600,660,850,1,000$, and $1,500 \mathrm{~kW}$. Table 4 shows their nominal and estimated annual energy productions and capacity factors. Capacity factor is the ratio of estimated and nominal annual energy productions. Turbine with $1500 \mathrm{~kW}$ nominal power has the highest capacity factor. The second highest capacity factor is achieved for a $600 \mathrm{~kW}$ nominal power turbine which is used commercially very commonly. Thus, both turbines were chosen as the most suitable wind turbines for the campus area.

Wind speed and wind energy maps were used to select suitable sites to locate wind turbines. Four sites were selected to install $600 \mathrm{~kW}$ turbines. Their hub heights and rotor diameters were 46 and $44 \mathrm{~m}$, respectively. These sites have mean speed more than $8 \mathrm{~m} / \mathrm{s}$ and enough area to locate these turbines. Turbines were located $150 \mathrm{~m}$ distance apart each other to prevent energy production loses of park effect. Fig. 4 shows those 47 turbines which were located as aligned position in four sites according to the prevailing wind direction. Calculated energy production of located 47 turbines with total capacity of 28.2 MW was 100.3 GWh. Two sites were selected to install $1500 \mathrm{~kW}$ turbines. Their hub heights and rotor diameters were, 60 and $64 \mathrm{~m}$. Fig. 5 shows those 26 turbines which were located $250 \mathrm{~m}$ distance apart and aligned according to the prevailing wind direction.

Table 4

Comparison of turbines

\begin{tabular}{lcll}
\hline $\begin{array}{l}\text { Turbine power } \\
(\mathrm{kW})\end{array}$ & $\begin{array}{l}\text { Nominal annual energy } \\
\text { production }(\mathrm{MWh})\end{array}$ & $\begin{array}{l}\text { Estimated annual energy } \\
\text { production }(\mathrm{MWh})\end{array}$ & $\begin{array}{l}\text { Capacity factor } \\
(\%)\end{array}$ \\
\hline 600 & 5256 & 2196 & 41.8 \\
660 & 5781.6 & 2405 & 41.6 \\
850 & 7446 & 3076 & 41.3 \\
1000 & 8760 & 3478 & 39.7 \\
1500 & 13,140 & 5927 & 45.1 \\
\hline
\end{tabular}




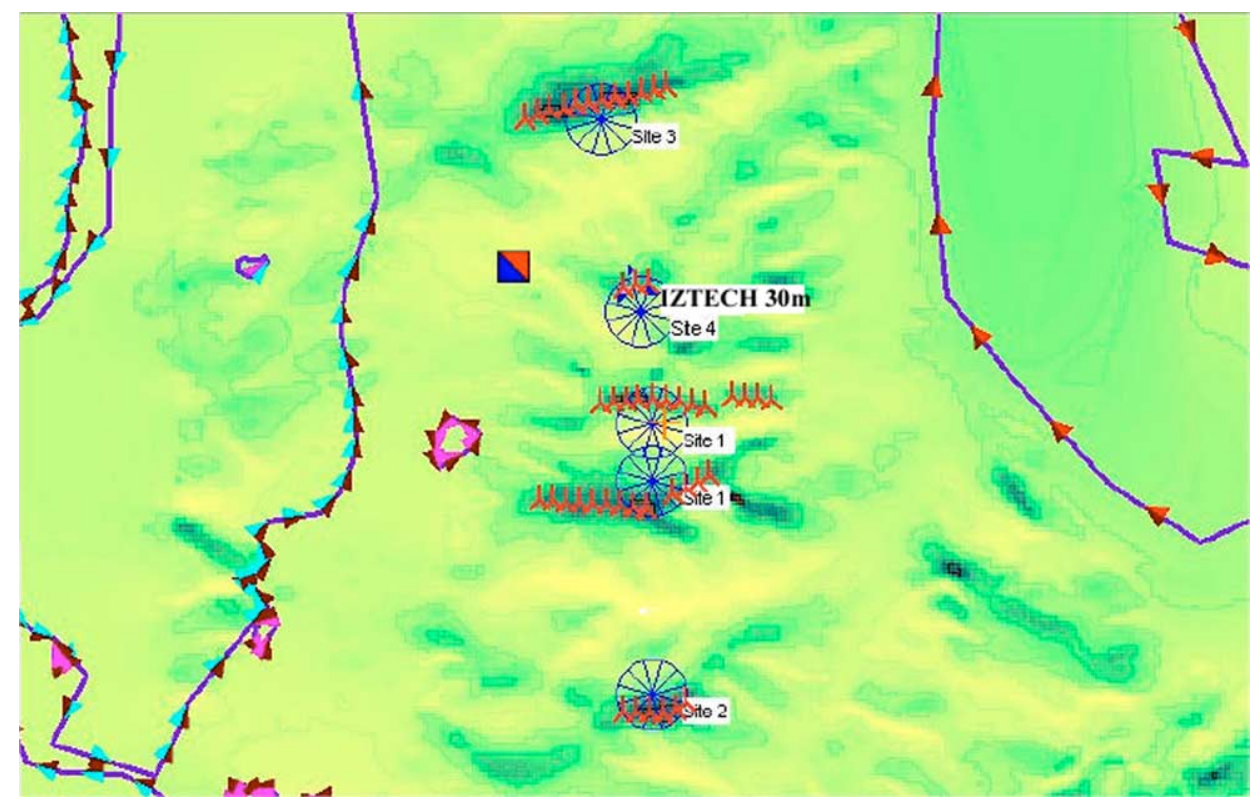

Fig. 4. Micrositting of $600 \mathrm{~kW}$ turbines on the campus area.

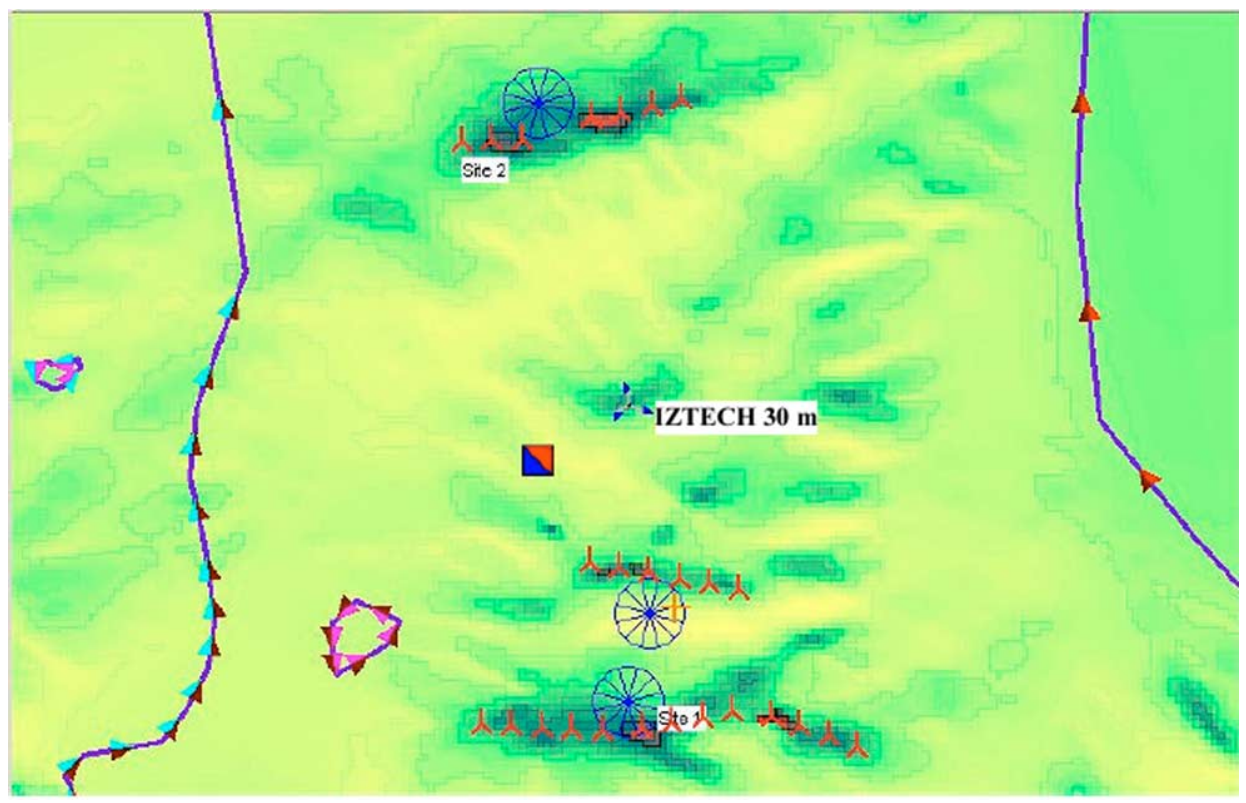

Fig. 5. Micrositting of $1500 \mathrm{~kW}$ turbines on the campus area. 
Calculated energy production of 26 turbines with total capacity of $39 \mathrm{MW}$ was 122.4 GWh.

\section{Conclusion}

The aim of this study was to estimate wind energy potential and to perform the most suitable micrositting study. The presence of high wind speed and, therefore, high wind power on Izmir Institute of Technology campus area were explicitly demonstrated. The wind power parameters were evaluated by using a great deal of measured data. Mean speeds were $7.03 \mathrm{~m} / \mathrm{s}$ at $10 \mathrm{~m}$ height and $8.14 \mathrm{~m} / \mathrm{s}$ at $30 \mathrm{~m}$ height. North was found as prevailing wind direction. In addition to wind characteristics, wind energy map was created. The most suitable turbines were located at the most convenient sites in order to utilize wind power. The annual energy productions of the micrositted turbines with 600 and $1500 \mathrm{~kW}$ nominal powers were, respectively, 100.3 and $122.4 \mathrm{GWh} /$ year. The result derived from this study encourages the utilization of wind power especially in the western Anatolia region of Turkey which has a long coast to Aegean Sea.

\section{Acknowledgements}

The authors gratefully acknowledge the Izmir Institute of Technology Research Fund for the financial support of the present study through project AFP-2001 MÜH 01.

\section{References}

[1] Long Term Strategy and Eight Five-Year Development Plan (2001-2005), State Planning Organization, Ankara-Turkey; 2001.

[2] 2002 Energy Statistics, World Energy Council Turkish National Committee, Istanbul-Turkey; 2003.

[3] Brown BG, Katz RW, Murphy AA. Time series models to simulate and forecast wind speed and wind power. J Appl Meteorol 1984;23:1184-95.

[4] Blanchard M, Desrechors G. Generation of auto-correlated wind speeds for wind energy conversion system studies. Sol Energy 1984;33:571-9.

[5] Chou KC, Corotis RB. Simulation of hourly wind speed and array wind power. Sol Energy 1981;26: 199-212.

[6] Bernard JC. An evaluation of three models designed for sitting wind turbines in areas of complex terrain. Sol Energy 1991;46:283-94.

[7] Landberg I, Mortensen NG, Petersen EL. Wind resource assessment and sitting-a wider perspective. World directory of renewable energy suppliers and services 1995 (p. 170-176).

[8] Troen I, Petersen EL. European Wind Atlas. Roskilde: Riso National Laboratory; 1989.

[9] Starkov A, Landberg L. Wind Atlas of Russia. In: Petersen EL, editor. Proceedings of the European wind energy conference, Nice-France, 1999. p. 1128-31.

[10] Watson R, Landberg L. The Irish Wind Atlas. In: Petersen EL, editor. Proceedings of the European wind energy conference, Nice, France, 1999. p. 1097-100.

[11] Tolun S, Menteş S, Aslan Z, Yükselen MA. The wind energy potential of Gokceada in the northern Aegean Sea. Renew Energ 1995;6(7):679-85. 
[12] İncecik S, Erdoğmuş F. An investigation of the wind power potential of the western coast of Anatolia. Renew Energ 1995;6(7):863-5.

[13] Şen Z, Şahin AD. Regional assessment of wind power in western Turkey by the cumulative semivariogram method. Renew Energ 1997;12(2):169-77.

[14] Türksoy F. Investigation of wind power potential at Bozcaada, Turkey. Renew Energ 1995;6(8):917-23.

[15] Dündar C, İnan D. Investigation of wind energy application possibilities for a specific island (Bozcaada) in Turkey. In: Sayigh A, editor. Proceedings of world renewable energy conference, Denver CO, 1996. p. 822-6. 